\title{
Přemluv bábu, protože je čeho se bát, aneb Waltonova argumentační schémata ve videu „Přemluv bábu"
}

\author{
Martin Prokop \\ Filozofická fakulta \\ Masarykova univerzita \\ Arna Nováka 1, 60200 Brno \\ martinprokop@mail.muni.cz
}

$\mathrm{V}$ textu představuji dva př́istupy $\mathrm{k}$ argumentační analýze: neformálně-logickou analýzu založenou na práci Ralpha H. Johnsona a J. Anthonyho Blaira a argumentační schémata od Douglase Waltona. V první části definuji oba dva přistupy a vysvětluji jejich vzájemný vztah. Dále vysvětluji základní pojmy obou přístupů - definuji argument, interní argument, implicitní premisu a PZstrukturu, argumentační schéma a kritické otázky. Věnuji se i popisu jejich výhod a nevýhod. $\mathrm{V}$ druhé, praktické části textu aplikuji definované nástroje na video Přemluv bábu. Formuluji tři výzkumné otázky, na které odpovídám. V rámci odpovědi na první předkládám PZ-strukturu argumentace $\mathrm{z}$ videa. Záměrem druhé otázky je identifikace argumentačních schémat $\mathrm{v}$ analyzované struktuře, kde považuji za nejdůležitější argument apelující na strach. Účelem poslední otázky je hledání odpovědí na kritické otázky související s identifikovaným schématem. Docházím $\mathrm{k}$ závěru, že protagonisté argumentu neodpovídají na otázky uspokojivě. Záměrem textu je předložit případovou studii, na které ukážu, jak analyzovat argumentační text pomocí zvolených přístupů.

Klíčová slova: argumentace, analýza, neformálně-logická analýza, kritické otázky, Douglas Walton, Přemluv bábu 


\section{1. Úvod}

Cílem textu je ukázat čtenáři možnosti moderní argumentační analýzy na konkrétním materiálu, videu Přemluv bábu ${ }^{1}$. Pro tento účel jsem si vybral dva z aktuálních analytických nástrojů. Prvním z nich je neformálně-logická analýza, druhým je analýza pomocí argumentačních schémat.

První nástroj vznikal v průběhu 6o. let a za jeho přední představitele jsou považováni ${ }^{2}$ dva kanadští filosofové, Ralph H. Johnson a J. Anthony Blair, kteří shrnuli svi̊j přístup v knize Logical self-defence ${ }^{3} \mathrm{z}$ roku 1977. Škola neformální logiky je pak zastřešující pojem pro velmi široký proud přístupů $\mathrm{k}$ analýze argumentace a tzv. kritickému myšlení, ${ }^{5}$ do něhož lze začlenit víceméně všechny projekty ${ }^{6}$ analýzy textu od 6o. let, které překračují formálně logický př́stup. ${ }^{7} \mathrm{~V}$ textu budu pracovat s nástrojem v podobě, kterou předložili Johnson a Blair ve zmíněné knize.

Abych ukázal, jaký měla neformálně-logická analýza vliv a jak se změnila, provedu dále analýzu pomocí argumentačních schémat, která uceleně předložil Douglas Walton roku 2008 v knize Argumentation schemes $^{8}$. Ani argumentační schémata nejsou dílem jednoho člověka. Přístup vznikal už v 90. letech a Walton je jeho nejvýznamnějším představitelem. ${ }^{9}$ Zmíněná kniha je jeho opus magnum, které obsahuje vyčerpávající kompendium všech jím popsaných schémat, ale i těch převzatých od dalších autorů. Waltonova práce je příkladem rozvinutí paradigmatu, které bylo nastoleno v 6o. letech neformálně-logickou školou.

Čtenář tak může $\mathrm{v}$ následujícím textu vidět, jak lze analyzovat argumentační text pomocí neformálně-logické analýzy, která znamenala

1 Issová, Mádl \& Zelenka (2010). Odkaz na video a přepis celého textu je k dispozici v editorialu tohoto čísla časopisu na s. 7-9.

2 Groarke (2017, kap. 1).

3 Blair \& Johnson (2006). Pracuji s aktualizovaným a doplněným vydáním z roku 2006.

4 Srovnej Groarke (2017).

5 Srovnej Siegel (1988, ix-xi).

6 Srovnej Groarke (2017, kap. 6). Zde je seznam základních okruhů témat, jimž se autoři, které lze označit za členy Školy neformální logiky, věnují.

7 Srovnej Hansen \& Cohen (2011).

8 Walton, Reed \& Macango (2008).

9 Tamtéž, s. 8-9. 
revoluci v přístupu $\mathrm{k}$ analýze argumentace. A dále, kam až tento přístup dospěl v podobě argumentačních schémat.

\section{1. Neformálně-logický prístup}

Cílem Johnsona a Blaira bylo vytvořit nástroj pro studenty, pomocí kterého by mohli snadno analyzovat a hodnotit argumenty, se kterými se setkávají v běžném životě, v médiích, v politických debatách a v reklamě, zkrátka všude ve veřejném prostoru. Předmětem jejich zájmu byl rozvoj schopnosti kritického přístupu k informacím, která má vést k lepší orientaci v moderní společnosti, práci, životě i vzdělávání, což povede $\mathrm{k}$ větší odolnosti proti manipulacím a dezinformacím, $\mathrm{s}$ nimiž se setkáváme. Výsledkem práce byla kniha Logical self-defence, která obsahuje nezbytnou teorii a množství rad i praktických cvičení.

Výchozím bodem knihy je tvrzení, že klasická formální analýza argumentů, spočívající na výrokové a predikátové logice, není dostatečným nástrojem $\mathrm{k}$ popisu běžných argumentů. Formální analýza totiž nezachytí důležité části argumentů, které se nacházejí mimo logické vztahy premis a závěru. Navíc v běžném životě ani lidé formální argumenty nepoužívají. Autoři ovšem na logickou analýzu nerezignují, ale rozšiřují ji. ${ }^{10}$ Jejich pojetí argumentace je tak obecnější a umožňuje větší množství našich promluv rekonstruovat jako argumenty. To sice více odpovídá našim potřebám, ale na druhou stranu se tím nutně ztrácí rigoróznost formální analýzy.

Argumentace je Johnsonem a Blairem definována jako spor ve stanoviscích, kdy nejméně dvě strany vyjádří své názory a přidají důvody, které je k nim vedou. Nestačí přitom, aby strany pouze deklarovaly nesouhlas. ${ }^{11} \mathrm{Z}$ definice je zřejmé, že předmětem argumentace musí být tvrzení, které obě strany považují za kontroverzní. K podpoře svých stanovisek používají aktéři sporu argumenty: argument je soubor jednoho nebo více tvrzení - premis -, které společně tvoří důvody pro přijetí závěru. ${ }^{12}$

10 Blair \& Johnson (2006, s. xiii).

11 Tamtéž, s. 7.

12 Tamtéž, s. 10. 
Johnson a Blair nám doporučují zapisovat argumenty do tzv. PZstruktury (zkratka pro strukturu premisy-závěr), jejíž hlavní výhodou je možnost zachytit vztahy mezi jednotlivými premisami a závěrem. Výsledkem je stromová struktura, která může být rozvětvena libovolně do hloubky i šíŕky. Jako př́klad PZ-struktury uved’me část argumentu $\mathrm{z}$ videa, který podrobněji představím níže.

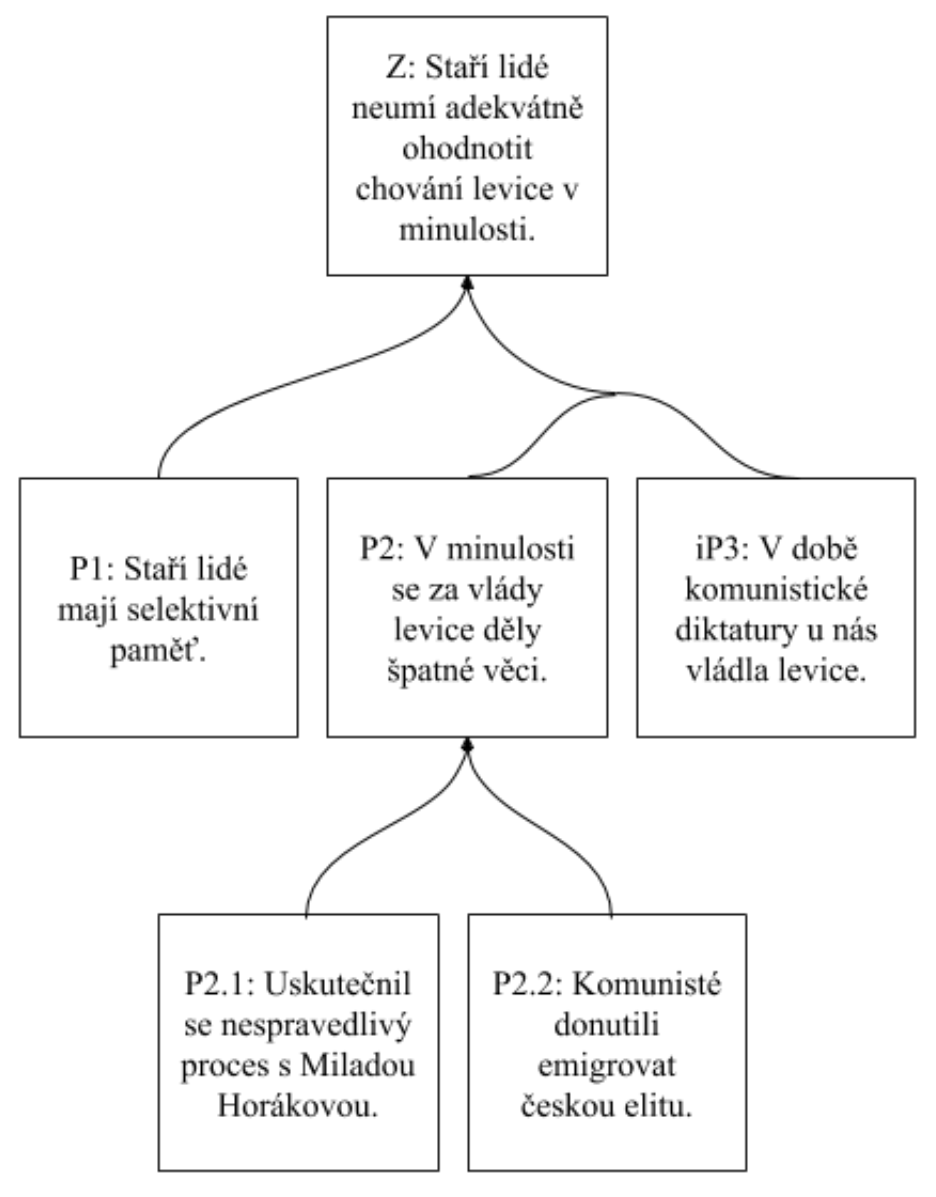

Závěrem argumentu je tvrzení, že staří lidé neumí adekvátně ohodnotit chování levice $\mathrm{v}$ minulosti, což je podpořeno třemi premisami. Tato 
čtyři tvrzení sama o sobě tvoři jednoduchý argument. $\mathrm{K}$ pochopení jeho struktury je důležité znát další pojem, a to interní argument. ${ }^{13}$ Ve třetí úrovni struktury totiž najdeme další dvě premisy (P2.1 a P2.2), které podporují premisu P2. Z hlediska celého argumentu jde o interní argument se závěrem $\mathrm{P} 2$. Jedná se v podstatě o označení menšího argumentu uvnitř většího argumentačního celku. $\mathrm{V}$ pozadí ideje interního argumentu stojí úvaha, že argumentace je modulární struktura, která se může zanořovat a jejíž podskupiny lze chápat jako samostatné argumenty. $Z$ tohoto hlediska můžeme Johnsonův a Blairův pojem interní argument chápat synonymně s pojmem podargument.

Dalším specifikem PZ-struktury je implicitní premisa, v případě naší analýzy iP3, kterou označujeme prefixem „i“. Implicitní premisy nejsou v textu vyjádřeny přímo, ale přesto jsou součástí argumentu. ${ }^{14}$ Při jejich formulaci se máme řídit principem vstř́ícnosti, podle nějž jsme zavázáni rekonstruovat argumenty tak, jak by je sám autor pravděpodobně zamýšlel. ${ }^{15}$ Implicitní premisa má za prvé tvořit společně s ostatními premisami relevantní podporu závěru, za druhé má být přijatelná pro předkladatele argumentu a nakonec by ji měl předkladatel argumentu sám chtít předložit publiku, jemuž je argument určen.

Poslední aspekt, který lze PZ-strukturou zachytit, můžeme také ukázat pomocí výše popsaného argumentu. Johnson a Blair popisují situace, kdy jsou premisy argumentu spojené a kdy jsou naopak nezávislé. Identifikace těchto dvou typů vztahu mezi premisami nám dává možnost popsat důležitý rozdíl v tom, jak premisy podporují závěr.

Závěr argumentu $\mathrm{Z}$ je podporovaný premisami $\mathrm{P} 2 \mathrm{a}$ iP3, které jsou spojené, což znamená, že podporují závěr jenom tehdy, jsou-li použity společně. ${ }^{16}$ Pokud např́lklad odstraníme premisu iP 3 , ztratí se informace o tom, že to, co se dělo za komunismu, zavinila levice. Nebude pak zřejmý vztah mezi komunistickou diktaturou a současnou levicí, a závěr nebude ze zbylé premisy $\mathrm{P} 2$ vyplývat.

Oproti tomu premisy P2.1 a P2.2 jsou nezávislé a, pokud bych jednu z nich odstranil, pořád bych měl argument, byt’ by byl jeho závěr

13 Tamtéž, s. 33.

14 Tamtéž, s. 34.

15 Tamtéž, s. 15.

16 Tamtéž, s. 35-40. 
podepřený jen jedním důvodem. Pokud bych například odebral tvrzení P2.2, že komunisté donutili emigrovat českou elitu, měl bych pořád premisu P2.1, která by podporovala tvrzení, že se v minulosti za vlády levice děly špatné věci.

Vidíme, jak důležitou roli hraje typ vztahu $\mathrm{v}$ tom, jak je závěr podporován. Zachycení vztahu je proto velmi důležité a často rozhoduje o tom, vyplývá-li závěr z premis, nebo ne. Znalost typu vztahu premis může být využita i při kritice argumentu. Pokud vyvrátíme jednu ze spojených premis výše uvedeného podargumentu, závěr nebude dostatečně podporován.

Součástí PZ-struktury bývá i parafráze celého argumentu, která v co nejkoncentrovanější podobě sděluje podstatu argumentu a mohla by ho tedy nahradit. $V$ případě tohoto argumentu by mohla znít:

Stař́ lidé neumí adekvátně ohodnotit chování levice $v$ minulosti, protože majı́ selektivní pamět’ a protože si nepamatují, že se za vlády levice $v$ období komunistické diktatury děly špatné věci, jako např́klad nespravedlivý proces s Miladou Horákovou nebo to, že byla elita národa nucena $k$ emigraci.

Výše popsané aspekty Johnsonova a Blairova přistupu nám dávají do rukou nástroje, pomocí kterých můžeme argumenty rekonstruovat. I hodnocení argumentů se $\mathrm{v}$ jejich přístupu liší od formální logiky. Např́klad argument výše není ani deduktivní - závěr neplyne nutně z premis -, ani induktivní - závěr není pravděpodobný -, ale přesto ho lze přijmout.

Podle Johnsona a Blaira se dobré argumenty poznají tak, že splňují tři kritéria známá pod zkratkou RSA: relevance, sufficience, acceptabillity ${ }^{17}$. Relevanci definují jako schopnost premisy podporovat závěr, a to určitou vahou: závěr může být podporován dvěma různě relevantními premisami. ${ }^{18}$ Dostatečnost je dána schopností premisy poskytnout evidenci pro důvodné přijetí závěru - dostatečné premisy mají poskytovat

17 Překládám jako relevance, dostatečnost a přijatelnost.

18 Blair \& Johnson (1984, s. xiv a s. 67). 
dostatečnou evidenci a poukazovat na neexistenci opačné evidence. ${ }^{19}$ A přjiatelnost je dána tím, zda předkladatel i prŕjjemce argumentu považují argument za přjiatelný - $\mathrm{k}$ tomu nesmí předkladatel použít argument bez dostatečné obhajoby. ${ }^{20}$ Splnění kritérí bude často předmětem další debaty mezi stranami. A to nepochybně kvưli vágnosti kritérií, hlavně z důvodu jejich závislosti na osobním hodnocení těch, co je interpretují. Na druhou stranu právě díky tomu umožňuje neformálnělogická analýza studovat široké spektrum argumentů, které by formální analýza rovnou odmítla. Pokud argument nesplní jednu ze tří podmínek, jedná se o argumentační chybu ${ }^{21}$. Tu můžeme popsat podle toho, jaké kritérium je v ní porušeno. ${ }^{22}$

Ačkoliv se může dnešnímu čtenáři zdát představený př́istup banální,je třeba si uvědomit, jak velkou změnu znamenal v době vzniku. Umožňuje analyzovat velké množství argumentů, jejichž význam není možné formální analýzou zachytit. Nejsme ovšem schopni do analýzy zahrnout nevyjádřený kontext argumentů, jako jsou motivace předkladatele, rétorické aspekty, okolnosti předložení argumentu, epistemologické souvislosti atd.

Lze říci, že všechny další př́istupy k analýze argumentace prezentované v této publikaci musí nejprve zkoumaný text podrobit neformálně-logické analýze a až potom mohou rozvíjet podrobnější analýzu zaměřenou na jemnější nuance argumentace. $Z$ toho také vyplývá, že zůstat dnes $\mathrm{u}$ neformálně-logické analýzy není vhodné, nebot’ máme $\mathrm{k}$ dispozici propracovanější nástroje, které ji rozšiřují. ${ }^{23}$

\section{2. Waltonova argumentační schémata}

Douglas Walton nepochybuje, že většina argumentů, se kterými se setkáváme, je neformální. Středem jeho zájmu jsou argumenty z běžného života, ale věnuje pozornost $i$ argumentům v oblasti práva a komunikace vědy.

19 Blair \& Johnson (2006, s. 72).

20 Tamtéž, s. 78.

21 V originále fallacy. Často bývá překládáno jako argumentační faul.

22 Srovnej Blair (2011, s. 87-88).

23 Právě ostatní přístupy pojednávané v této publikaci ukážou, na jaké všechny nuance argumentace se lze zaměřit. 
Argumentační schémata jsou formy argumentů, které reprezentují vnitřní strukturu běžných typů argumentů. ${ }^{24}$ Jde tedy o abstrakce argumentů, které mají místo konkrétních premis a závěru proměnné, za něž můžeme dosazovat libovolná tvrzení. Ve většině př́ípadů jsou schémata formulována ve formě modus non excipiens ${ }^{25}$, který má stejnou strukturu jako deduktivní argument modus ponens, ale jehož závěr neplyne z premis nutně. Ovšem ne všechna schémata se dají zapsat takto jednoduše, jejich struktura je složitější. ${ }^{26}$ Jako př́klad schématu ve formě modus non excipiens lze uvést argument $z$ populárního názoru ${ }^{27}$, který spočívá $\mathrm{v}$ přijetí toho, co je obecně považováno za pravdivé. $^{28}$

P1: Pokud je tvrzení A obecně přijímáno jako pravdivé, je to důvod přijmout, že je tvrzení A pravdivé.

P2: Tvrzení A je obecně přijímáno jako pravdivé.

$Z$ : Můžeme přijmout, že je tvrzení A pravdivé.

Kromě toho, že schémata usnadňují pochopení argumentů, slouží především k jejich hodnocení. Podle Waltona je jen malá část argumentů deduktivních, nebo induktivních, většina jich je tzv. vyvratitelných ${ }^{29}$. Závěry těchto argumentů nevyplývají z premis nutně (respektive pravděpodobně jako $\mathrm{v}$ př́padě induktivních argumentů), ale poskytují pouze podporu $\mathrm{k}$ jejich provizornímu přijetí. ${ }^{30}$ Hodnocení a následné přijetí, nebo nepřijetí takových argumentů proto nemůže být založené pouze na zjištění vztahu premis a závěru pomocí formální analýzy (respektive pravděpodobnostního vztahu), ale na analýze kontextu.

\footnotetext{
24 Walton, Reed \& Macango (2008, s. 1), Walton \& Reed (2007), Walton (2005), Walton \& Macango (2013).

25 (1) Pravidlo P stanoví, že A -> B; (2) platí A; (Z) pokud se nejedná o výjimku z pravidla P, platí B. 26 Walton, Reed \& Macango (2008, s. 364-367).

27 Překládám $\mathrm{z}$ anglického argument from popular opinion.

28 Walton, Reed \& Macango (2008, s. 311), srovnej Walton \& Reed (2002, s. 1-2).

29 Překládám Waltonův termín pro kategorii argumentu defeasible. Lze se setkat i s termíny zamítnutelný a zrušitelný. Srovnej Ondráček \& Štěpánek (2016, s. 18) a Pezlar (2012, s. 42).

30 Walton, Reed \& Macango (2008, s. 367).
} 
Kritérium pro přijetí argumentu je dáno požadavkem, aby předkladatel argumentu odpověděl na kritické otázky ${ }^{31} \cdot 3^{22}$ Každé argumentační schéma má k sobě přidruženu skupinu kritických otázek, jejichž smyslem je otestovat kritická místa argumentu. ${ }^{33}$ Podle Waltona totiž probíhá argumentační výměna v několika krocích. V prvním kroku předkládá jedna strana argument straně druhé, aby ji přesvědčila o svém stanovisku. $\mathrm{V}$ druhém kroku má př́jemce argument identifikovat jako instanci konkrétního argumentačního schématu. Dále pak má položit předkladateli kritické otázky, na které je povinen odpovědět. ${ }^{34}$ Odpovíli předkladatel na vše uspokojivě, př́jemce by měl závěr argumentu přijmout. Samozřejmě ale ještě musí posoudit to, jak silně podporují premisy závěr ${ }^{35}$, dodává Walton. ${ }^{36}$ To jinými slovy znamená, že i když argument obstojí při zkoušce kritickými otázkami, ještě musíme zjistit, zda jsou důvody dostatečně silné. Pokud ovšem otázky nejsou zodpovězeny uspokojivě, je to pro nás signál, že je argument nejspíše chybný. Kritické otázky jsou úzce spojeny s argumentačním schématem. Výše zmíněné schéma argumentu z populárního názoru má přidruženy dvě otázky:

1. Existuje evidence jako třeba dotazník nebo obecně platná skutečnost, která podporuje fakt, že je tvrzení A obecně přijímáno?

2. Existují důvody $\mathrm{k}$ tomu, abychom pochybovali o tom, že je tvrzení A pravdivé, přestože je obecně přijímáno?

První otázka mírí na premisu P2 s cílem zjistit, zda lze zpochybnit skutečnost, že je tvrzení A obecně přijímáno. Cílem druhé otázky je zpochybnění závěru argumentu prostřednictvím útoku na princip formulovaný $\mathrm{v}$ první premise: skutečně $\mathrm{v}$ tomto konkrétním př́padě

31 Překládám Waltonův termín critical questions.

32 Srovnej Walton \& Godden (2007).

33 Srovnej Lumer (2016, s. 4).

34 Walton, Reed \& Macango (2008, s. 9).

35 Např́́klad u argumentu založeného na induktivním zobecnění pouze na dvou př́kladech z mnoha možných, nepodporují premisy závěr příliš silně.

36 Walton, Reed \& Macango (2008, s. 12). 
platí, že když je dané tvrzení obecně považováno za pravdivé, je pravdivé? Každé schéma má většinou tolik otázek, aby bylo možné otestovat všechny jeho premisy, závěr a jejich spojení. Walton zmiňuje, že často lze velmi těžko určit hranici mezi premisou ve schématu a kritickou otázkou. Otázku lze totiž snadno transformovat do další premisy argumentu, a naopak premisu lze ze schématu odebrat a ptát se doplňující otázkou na splnění podmínky, kterou premisa stanovuje. ${ }^{37}$

Jak je již patrné, Waltonovo pojetí argumentace je dialogické. ${ }^{38}$ Každý argument by mělo být možné zachytit pomocí dialogu dvou stran $^{39}$. Kritické otázky pak slouží jako způsob, kterým se přenáší důkazní břemeno mezi účastníky argumentační výměny. Obvykle totiž obě strany předkládají argumenty, vzájemně se dotazují na jejich smysl a přidávají další podargumenty, které zpochybňují, či rozšiřují předchozí. Kritické otázky jsou prostředek, jakým jedna strana požaduje od druhé, aby doložila důvody pro to, co tvrdí. Tuto povinnost nazývá neformální logika důkazní břemeno. Významnou roli hraje hlavně při hodnocení argumentace, protože pomocí něj můžeme zjistit, která strana má nesplněné závazky, pročež její argument není dostatečně podpořený.

Kritické otázky nemají pouze funkci evaluační, ale usnadňují i rekonstrukci argumentu. Pomáhají totiž při vyhledávání implicitních prvků. Pokud identifikujeme argument jako instanci schématu, víme, jaké premisy by měl mít. Ty pak můžeme v textu najít a doplnit. ${ }^{40}$ Díky tomu lze argument rekonstruovat $\mathrm{v}$ dostatečně silné podobě, pokud ho tak protistrana předložila. $V$ neposlední řadě mají kritické otázky i edukační funkci, nebot’ nám mohou pomoci při vytváření vlastních argumentů. Můžeme si je položit a předběžně na ně odpovědět ještě před tím, než argument předložíme.

Waltonova analýza pomocí argumentačních schémat tedy v mnoha ohledech usnadňuje hodnocení argumentů. Zopakujme, že Walton radí, abychom argument rekonstruovaný do PZ-struktury identifikovali jako instanci jednoho ze schémat a následně ho podrobili kritickým otázkám.

37 Tamtéž, s. $15^{-17}$.

38 Srovnej Walton \& Reed (2007).

39 Pokud např́iklad píšu argument v tomto článku, druhá strana je potenciální čtenář, jehož chci přesvědčit.

40 Walton, Reed \& Macango (2008, s. 21). 
V knize Argumentation schemes může čtenář najít přes 150 schémat. Jsou obecně formulované a většinou není těžké prriřadit argumenty pod některé z nich. Pokud předkladatel argumentu odpoví na všechny otázky uspokojivě, je to významnou známkou toho, že argument není vadný.

Nejčastější výhrady ${ }^{41}$ vůči Waltonovu přístupu směřují na nejednoznačnost klasifikace schémat ${ }^{42}$. Walton popisuje různé klasifikace, ale žádná není bez nejasností. Stanovuje přitom hlavním kritériem tvorby klasifikace její užitečnost. Klasifikace musí sloužit $\mathrm{k}$ výuce (musí být snadno pochopitelné, podle čeho se schémata dělí), zároveň musí vyhovovat uživatelům při analýze argumentace (musí se v ní snadno vyhledávat) a také má sloužit $\mathrm{k}$ snadné tvorbě vlastních argumentů. ${ }^{43}$ To ovšem znamená, že klasifikace schémat je arbitrární a neodráží vztahy mezi formami argumentu. Zpochybňování se nevyhnou ani kritické otázky. ${ }^{44}$ Diskutuje se především, zda má předkladatel argumentu skutečně povinnost na ně odpovídat. Pokud totiž nemá, nemohou přenášet důkazní břemeno. ${ }^{45}$ Neměly by pak přidanou hodnotu, protože by pouze opakovaly to, co už je dáno premisami schématu. Mohli bychom jim pak při nejlepším připsat edukační roli. $\mathrm{S}$ tím Walton nesouhlasí, podle něj je přidanou hodnotou kritických otázek právě přenos důkazního břemene..$^{46}$

Waltonův nástroj je velice vhodný $\mathrm{k}$ analýze argumentů, které lze snadno rozložit na velmi malé části. Jelikož má většina schémat formu modus non excipiens, musíme dokonce hledat nejjednodušší možné argumenty. Složitější argumentační celky je třeba pro tento účel rozdělit, a tak se stává, že komplexní argumenty se pomocí schémat analyzují mnohem náročněji. $Z$ povahy schémat nemůžeme ani očekávat, že bychom pomocí nich mohli analyzovat např́klad rétorické a dialektické aspekty argumentace či kontext spojený s motivy mluvčích. Přes všechny výhrady je tento směr analýzy uznávaný a používaný. Umožňuje nám

41 Pro přehledný seznam okruhů námitek vůči schématům viz Blair (1998, kap. 2).

42 Srovnej Freeman (2012, s. 9-10), van Eemeren et al. (2014, s. 404), Lumer (2016, s. 6).

43 Walton, Reed \& Macango (2008, s. 360-362).

44 Srovnej Hitchcock (2006, s. 23).

45 Walton, Reed \& Macango (2008, s. 30-34).

46 Tamtéž, s. 17. 
vcelku rychle a snadno identifikovat argument se schématem a podrobit ho pomocí kritických otázek hodnocení, které prověří slabiny typické pro toto schéma.

\section{Analýza}

\section{1. Výzkumné otázky}

Jak bylo řečeno výše, díky neformálně-logické analýze získáme PZstrukturu argumentace. Přestože tím nezachytíme všechny aspekty argumentace ve videu, považuji př́stup za přiměřený. Ostatní složky záznamu jako obraz, rétorická stránka a podobně tvoří pouze doplněk, který má usnadnit pochopení, zaujmout a pobavit.

Waltonův př́stup navazuje na neformálně-logickou analýzu tak, že vychází ze získané PZ-struktury. Získaný materiál popíši pomocí schémat, díky čemuž budu schopen rozhodnout, zda argumenty obstojí před kritickými otázkami. Schémata jsou podle Waltona určena $\mathrm{k}$ analýze debaty ve veřejném prostoru, a proto je jejich užití v tomto př́padě vhodné.

Zvolené př́stupy sice nezohledňují všechny myslitelné aspekty argumentace, to ale $\mathrm{v}$ našem případě nevadí. Předpokládám totiž, že protagonisté ${ }^{47}$ videa mají zájem na tom, aby jejich argumenty byly stabilní v psané podobě. Ve většině případů analýzy mluvené argumentace (připravené video nebo např́klad proslovy a přednášky) je tento předpoklad správný a, je-li toto omezení všem předem známo, je užití analýzy legitimní.

Výzkumnou otázku pro neformálně-logickou analýzu formulujeme následovně:

\section{O1: Jaká je PZ-struktura hlavního argumentu ve videu Přemluv bábu?}

Pro analýzu podle Waltonova př́stupu stanovuji dvě výzkumné otázky:

47 Pro jednoduchost předpokládám, že protagonisté videa Martha Issová a Jiří Mádl jsou zároveň autoři a předkladateli argumentu. Nezabývám se tedy okolnostmi, že autorem videa je filmový a divadelní režisér Petr Zelenka a že oba protagonisté pouze hrají určitou roli. Tyto nuance zvolený způsob analýzy neumožňuje zachytit. 
O2: Jaká argumentační schémata jsou obsažena v nalezené PZ-struktuře?

O3: Jsou v textu uspokojivě zodpovězeny kritické otázky, které se vztahují k nalezeným schématům?

První dvě otázky se týkají rekonstrukce argumentace, v rámci třetí otázky budu hodnotit předložené argumenty, přičemž se omezím na zkoumání, zda protagonisté předložili argumenty tak, aby obstály při kritickém dotazování. Cílem navrženého postupu není kritizovat protagonisty za nezodpovězení otázek, které jim nikdo nekladl. Položím si kritické otázky a pokusím se obhájit argumenty na základě obsahu videa, čímž poukáži na to, jak propracované argumenty protagonisté na poměrně malém prostoru předložili. ${ }^{8}$

\section{2. Identifikace argumentů}

Vyhledání relevantních pasáži $\mathrm{v}$ přepisu videa je pracné. Text je krátký, je tvořen zčásti dialogem Issové a Mádla, zčásti se ale oba protagonisté střídají v promluvě, přičemž na sebe nereagují. Informační a argumentační hutnost se stř́dá s plochostí následujících vět, které s předchozí argumentací nijak nesouvisí, ale přinášejí celkové odlehčení promluvy.

Ponechám proto pouze pasáže, ve kterých je řečeno něco kontroverzního, co může být jádrem sporu v oblasti volebního boje, a samozřejmě i podpory těchto kontroverzních tvrzení. Odstraňuji tedy části, které jsou z hlediska přesvědčování zbytečné - tzv. vsuvky. Pomůže mi, když si označím jednotlivé promluvy 49 čísly. Často stačí očíslovat věty, někdy jde ale o souvětí, odstavec, nebo dokonce jen části vět. Hledáme zejména opakování již řečeného, ilustrace, definice pojmů, nepodstatné okolnosti nebo informace typu kdo, co a kde řekl.

48 Pokud některé otázky nebudou zodpovězeny, umožní to čtenáři, aby si sám udělal představu, jakým námitkám by měli předkladatelé argumentů čelit a jestli lze na otázky odpovědět uspokojivě.

49 Jedno celistvé tvrzení, které obsahuje jednu myšlenku, kterou lze zachytit v PZ-struktuře jako jednu premisu nebo závěr. 
První krok je nutné provést pečlivě, protože jinak bych při něm mohl přijít o důležité myšlenky. Povšimněme si, že vyškrtnu nejspíše promluvy, které nejsou na první pohled přesvědčovací, ale mohou působit na posluchače, jako například humorné vložky. Také nezachytím rytmus a dynamiku střídání promluv protagonistů a jejich význam, kladení banálních dotazů, které vedou k zdůraznění některých myšlenek, ani opakování některých pasáží. Toto vše není z hlediska neformálnělogické analýzy zajímavé, byt' to nepochybně určitou roli v přesvědčování diváků hraje.

Dalším krokem je přeformulování nevyškrtaných pasáží do srozumitelných parafrází, čímž získám teze. Tezemi se myslí tvrzení, které budou tvořit závěry a premisy argumentů. Cílem je zlepšit pochopitelnost promluv a vyjasnit jejich obsah. Přitom je třeba dbát na to, abychom s jejich obsahem nemanipulovali, upravili ho do podoby, se kterou by mluvčí souhlasili, a zároveň ho formulovali tak, aby co nejpřesněji vyjadřoval to, co chtěl předkladatel sdělit.

Výsledek popsaného postupu aplikovaného na přepis videa ${ }^{50}$ vidíme $\mathrm{v}$ následujícím odstavci. Jsou v něm vyškrtané vsuvky a v hranatých závorkách parafráze promluv, které použijeme jako teze $\mathrm{v}$ následné rekonstrukci. Povšimněme si například vyškrtnuté pasáže z první promluvy, kde jsem odstranil přebytečnou informaci o tom, kdo mluví - představení Marthy Issové. Druhá promluva je také z hlediska argumentace zbytečná, pouze opakuje to, že máme přemluvit naše prarodiče. Dále jsem např́klad v osmé promluvě vyškrtl pasáž, která definuje pojem selektivní pamět', protože nepotřebuji ve výsledné rekonstrukci definici pojmu, ale obejdu se s pojmem samotným. V osmé a deváté promluvě jsem vyškrtl slova, kterými se ve videu Martha Issová vztahuje k nesprávně uvedeným obrázkům a které je možno chápat i jako promluvu k režii.

$50 \mathrm{~V}$ textu jsem z úsporných důvodů analyzoval pouze část přepisu videa obsahující hlavní argument. 
1. ${ }^{51}$ Martha Issová: „Kdybyste věděli, že můžete změnit osud týhle země tím, že navštívíte svoje prarodiče, zajeli byste za nima? No jasně, že jo. Teda pokud nejste úplně... Já jsem Martha Issová. Přemluu bábu!52" [Mladí lidé mají změnit osud České republiky k lepšímu, je-li to možné. $]^{53}$

2. Jiř́ Mádl.: „A taky přemluu dědu!“

3. M.I.: „To je Jirka Mádl. Jestli v týhle zemi zvítězí u př́štích voleb levice, tak za to budou moct starý lidi, protože to jsou ty, který levici volej. [Jestli v České republice zvítězí levice, bude to zásluhou starých lidí.] To můžou bejt lidi $z$ vaší rodiny. [Typičtí voliči levice jsou senioři a mohou být naši příbuzní.] To může bejt vaše teta, váš strejda, vaše babiěka..."

4. J.M.: „..véš děda."

5. M.I.: "No. A většinou ty lidi bydlej na vesniei. Jak je to možný?"

6. J.M.: "Prostě se tam narodili!“

7. M.I.: „Ne, jak je možný, že tulevieivolej? Copak voni zapomněli, jak to tady těch čtyřicet let, co byli komunisti u moci, vypadalo?" [Staří lidé neumí relevantně ohodnotit chování levice v minulosti.]

8. J.M.: „Starý lidi mají totiž tzv. selektivní pamět’. [Staří lidé mají selektivní pamět.] To znamená, že si pamatujou jenom ty hezký věei. Jak si dali popróé pusu na taneění zábavě, ale už třeba úplně zapomněli na proces s Miladou Horákovou. ... Ne, toje Rita Hayworthová." [Uskutečnil se nespravedlivý proces $\mathrm{S}$ Miladou Horákovou.]

9. M.I.: „Komunisti přinutili nejlepší lidi týhletý země k emigraci - Miloše Formana, Miloše Formana, Navrátilovou, Kunderu... Milana Kunderu. [Komunisté donutili emigrovat českou elitu.] My natáčíme tohleto video,

51 Čísla označují jednotlivé promluvy.

52 Vyškrtané pasáže - vsuvky.

$53 \mathrm{~V}$ hranatých závorkách jsou parafrázované teze založené na nevyškrtaném textu, který jim předchází. 
abysme vás přesvědčili, že se prostě máte sebrat, koupit si listek na autobus nebo na vlak nebo nasednout do auta a rozjet se za svejma prarodičema nebo rodičema na venkov a přesvědčit je, že mají volit pravici. " [Měli bychom přemluvit své prarodiče $k$ volbě pravicové strany.]

8. J.M.: „Starý lidi mají totiž tzv. selektivní pamět’. [Staří lidé mají selektivní pamět.] To znamená, že si pamatujou jenom ty hezký věei. Jak si dali poprué pusu na taneění zábavě, ale už třeba úplně zapomněli na proces s Miladou Horákovou. ... Ne, toje Rita Hayworthová." [Uskutečnil se nespravedlivý proces S Miladou Horákovou.]

9. M.I.: „Komunisti přinutili nejlepší lidi týhletý země $k$ emigraci - Miloše Formana, Miloše Formana, Navrátilovou, Kunderu... Milana Kunderu. [Komunisté donutili emigrovat českou elitu.]. My natáčíme tohleto video, abysme vás přesvědčili, že se prostě máte sebrat, koupit si listek na autobus nebo na vlak nebo nasednout do auta a rozjet se za svejma prarodičema nebo rodičema na venkov a přesvědčit je, že maǰ́ volit pravici. " [Měli bychom přemluvit své prarodiče $k$ volbě pravicové strany.]

\section{3. Rekonstrukce argumentů}

Výsledkem rekonstrukce je PZ-struktura. Jako první zapíši teze, tj. závěry argumentů, a k nim přidám podpory. Mou snahou je zachytit vztahy mezi podporami. Dále je potřeba doplnit implicitní premisy. Může mi při tom pomoci doplňovat implicitní prvky tak, abych vysvětlil chybějící kroky argumentace, kdy není plně zřejmé, díky čemu závěr z premis vyplývá.

Na základě výše proškrtané pasáže jsem získal PZ-strukturu jednoho složitějšího argumentu, který má šest premis, z nichž jedna je závěrem interního argumentu. Celkově jsem identifikoval 11 premis, přičemž čtyři z nich jsou implicitní. Závěrem argumentu, a tedy i teze videa, je tvrzení: Měli bychom přemluvit své prarodiče k volbě pravicové strany. 

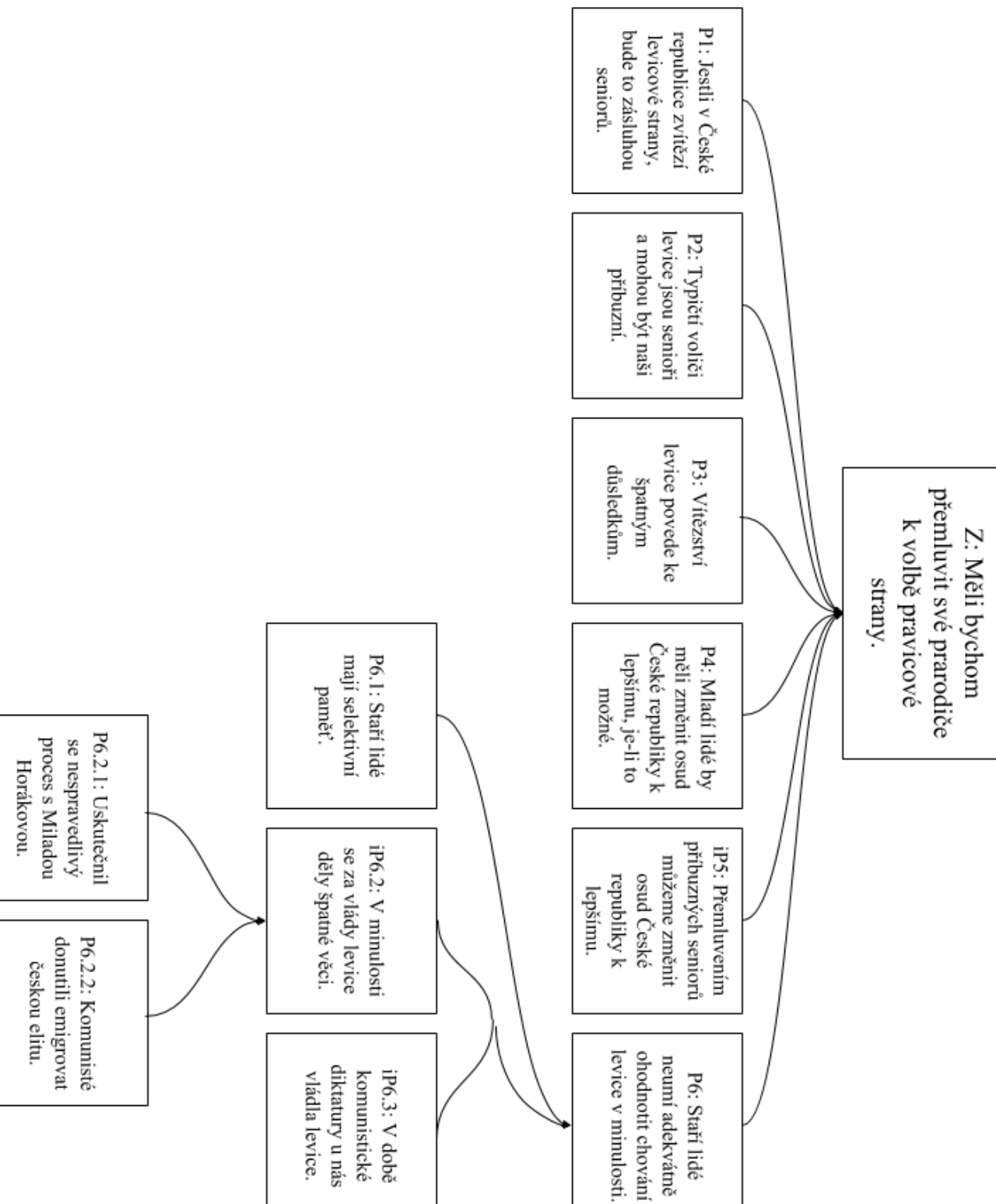
Seniory bychom měli přemluvit, protože podle P1 je jich tolik, že mohou rozhodnout o těsném vítězství levice ve volbách. Samozřejmě že k volbám nejdou jen senioři, ale tvoří významnou část všech voličù. Navíc jsou to podle premisy $\mathrm{P} 2$ typičtí voliči levice a mladí mají možnost některé z nich přesvědčit, protože jsou jejich př́ibuznými.

Dále protagonisté předpokládají, že vítězství levice ve volbách by vedlo ke špatným důsledkům, což dokládají v další části textu pomocí ukázek toho, v čem je a byla levicová politika špatná. Konkrétně lze ukázky špatných důsledků rozdělit do čtyř skupin. Protagonisté poukazují na neblahé dopady levicové politiky na státní rozpočet, na lékařskou péči, na důchodový systém a na školství. To vše zařazuji do argumentu jako premisu P3.

$\mathrm{V}$ premise $\mathrm{P}_{4}$ je předložena úvaha, že mladí lidé mají povinnost změnit osud země k lepšímu, je-li to v jejich silách. Tato úvaha je v textu formulována ve formě hypotetické úvahy a je podložena tvrzením, že snad každý by změnil osud země k lepšímu, měl-li by k tomu př́ležitost.

Pátá premisa $\mathrm{iP}_{5}$ uzavírá pomyslně úvahu tak, že právě přemluvením našich příbuzných seniorů, kteří volí levici, změníme osud země $\mathrm{k}$ lepšímu. Ta ale není v textu vyjádřena př́imo, a proto jsem ji doplnil jakožto implicitní premisu. ${ }^{54}$

Poslední premisa P6 slouží k vysvětlení motivi̊ seniorů k volbě levice. Tvrdí se v ní, že to dělají ze špatných důvodů, nebot' neumí adekvátně ohodnotit chování levice $\mathrm{v}$ minulosti. K tomuto tvrzení protagonisté došli pomocí interního argumentu, který má tři hlavní premisy. Podle premisy P6.1 mají staří lidé selektivní pamět a kvůli ní si pamatují pouze dobré věci, ale ne ty špatné. Tato premisa nezávisle podporuje závěr, že staří lidé nejsou kompetentní ohodnotit levici. Zapomněli, jak se tvrdí v implicitní premise iP6.2, že se za vlády levice děly špatné věci. To je podporováno dvěma nezávislými premisami, které uvádějí příklady událostí, jež se děly v době komunistické diktatury. Premisa iP6.2 je spojená s implicitní premisou iP6.3, že v období komunistické diktatury v České republice vládla levice. Mnoho zástupců levice by s tímto skrytým předpokladem nesouhlasilo. Jak víme, i současná KSČM, levicová strana,

54 Ačkoliv může tato premisa působit nadbytečně vzhledem $\mathrm{k}$ podobě předchozí premisy $\mathrm{P} 4$, její důležitost bude patrná v další části textu. Ukáže se, že $\mathrm{P}_{4}$ a iP 5 odpovídají dvěma různým premisám identifikovaného argumentačního schématu. 
se zdráhá identifikovat s některými historickými událostmi, které se za komunismu děly, ačkoliv její oponenti ji s nimi stále spojují. Nemluvě o tom, že do voleb kandidovaly i jiné levicové strany. Proto jsem tento předpoklad zařadil jako implicitní premisu.

Parafrázi nalezeného argumentu volím následovně:

Měli bychom přemluvit své prarodiče $k$ volbě pravicové strany, protože naši př́buzní senioři jsou typičtí voliči levice, díky kterým může levice vyhrát. Zvolení levice ale povede ke špatným dưsledkưm a my jsme povinni změnit osud České republiky $k$ lepšímu, máme-li jak. A právě přemluvením seniorů, kteři neumí adekvátně ohodnotit chování levice $v$ minulosti, změníme osud země k lepšímu.

Podařilo se mi zachytit PZ-strukturu, díky níž vidíme v přehledné podobě strukturu argumentace ve videu včetně vztahů mezi jejími jednotlivými částmi. Vyškrtal jsem zbytečné části a parafrázoval do pochopitelnější a jasnější podoby promluvy protagonistů. Doplněním implicitních prvků jsem ukázal argumentaci ve stabilnější a pochopitelnější podobě. Tím vším jsem odpověděl na první výzkumnou otázku.

Neformálně-logická analýza se ukázala jako vhodný základní nástroj pro práci se zvoleným materiálem. Na konkrétním příkladu jsem tak ukázal, jak neocenitelným nástrojem tento přístup je. Jak jsem zmínil výše, je tato práce pouze přípravou pro detailnější analýzu založenou na jemnějších nástrojích.

\section{4. Analýza argumentů}

Klíčovým nástrojem analýzy jsou Waltonova argumentační schémata. Při hledání vhodného schématu si můžeme pomoci parafrází argumentu. Podle ní jsou př́ijemci argumentu nabádáni k tomu, aby přesvědčili prarodiče k volbě pravice, čímž změní osud země k lepšímu - v opačném případě bude osud České republiky špatný.

Motivem argumentu jsou tedy jisté nežádoucí důsledky, kterým lze ale určitým činem zabránit. To by pro nás mělo být vodítko k vyhledání 
vhodné kategorie argumentačních schémat, do nichž by mohl argument spadat. Walton uvádí skupinu schémat z oboru praktického usuzovánín ${ }^{55}$, založených na důsledcích jednání, ty dále člení na argumenty založené na pozitivních a negativních důsledcích. ${ }^{56}$

$\mathrm{V}$ našem př́ípadě se jistě nebude jednat o argument založený na pozitivních důsledcích. Pozitivní důsledky jsou sice pro protagonisty žádoucí, ale jejich hlavním cílem je vyhnout se důsledkům negativním tedy zvolení levice. Můžu tedy předpokládat, že předložený argument je př́kladem schématu argumentu z negativních důsledků ${ }^{57}$.

Ovšem Walton je v této oblasti důslednější a rozlišuje tři podskupiny tohoto argumentu..$^{8}$ Mluví o argumentu apelujícím na nebezpečí59, argumentu apelujícím na strach ${ }^{60}$ a argumentu z ohrožení ${ }^{61} .{ }^{62}$ První se od zbylých dvou liší tím, že neobsahuje emocionální složku, ale pouze se v něm konstatuje existence objektivního nebezpečí, kterému je potřeba se určitým jednáním vyhnout.

To ovšem není př́pad argumentace ve videu. Issová a Mádl emoce zjevně používají. Dělají to pomocí doprovodného obrazového materiálu, např́klad ilustrací pohlavního orgánu, sugestivními obrázky seniorů v nepř́iliš lichotivé podobě, ale i pomocí řeči samotné. Dále př́ijemcům na konci videa nabízí vulgární formu odměny. Naznačují, že bychom byli přinejmenším hlupáci, pokud bychom nechtěli prarodiče přesvědčit. Dalším emotivně zabarveným momentem je analogie mezi politickou pravicí a levicí a tím, $\mathrm{k}$ čemu se použíá pravá a levá ruka. Podle této analogie si s námi levice „vytře zadek“ tak, jako se v některých částech světa používá $\mathrm{k}$ této činnosti levá ruka. A tím výčet emotivních momentů ve videu nekončí.

$\mathrm{V}$ dalších dvou podtypech schématu jsou emoce použity $\mathrm{k}$ tomu, aby pomohly přesvědčit př́jemce argumentu. Varianta argumentu z ohrožení oproti argumentu apelujícímu na strach musí podle Waltona splňovat tři

\footnotetext{
55 Překládám z anglického practical reasoning.

56 Walton, Reed \& Macango (2008, s. 100-102).

57 Překládám $\mathrm{z}$ anglického argument from negative consequences.

58 Walton, Reed \& Macango (2008, s. 102-106).

59 Překládám z anglického argument from danger appeal.

60 Překládám z anglického argument from fear appeal.

61 Překládám $\mathrm{z}$ anglického argument from threat.

62 Srovnej Walton (2013).
} 
podmínky. ${ }^{63}$ Za prvé má mít příjemce argumentu důvod domnívat se, že to, zda negativní důsledky nastanou, má pod kontrolou předkladatel argumentu. Dále oba, př́ijemce i předkladatel, mají důvod se domnívat, že důsledky nejsou v zájmu př́ijemce, a ten se jim proto chce vyhnout. A za třetí předkladatel tvrdí, že důsledky nastanou, pokud př́ijemce nevykoná určitou akci. Tento argument je tedy spíše jistou formou nátlaku nebo dokonce vyhrožování. Předkladatel nutí př́jemce udělat něco a odůvodňuje to tím, že v opačném případě by pro příjemce nastaly nežádoucí negativní důsledky. Takto silnou formu přesvědčování ovšem ve videu není vidět. Nelze mluvit o tom, že by Issová a Mádl vyhrožovali.

Na pomyslné škále míry tlaku na př́ijemce je argument apelující na strach uprostřed mezi dalšími dvěma typy. Upozorňuje totiž př́ijemce na nebezpečí a používá $\mathrm{k}$ tomu emocionální složku, ale nevyhrožuje. Máme mít z důsledků strach, který nás bude motivovat k vykonání činu, jenž by důsledky odvrátil. Issová a Mádl chtějí, abychom se báli, že bude státní kasa v budoucnu prázdná, že se nám kvo̊li levicové politice nedostane kvalitní lékařské péče, že nezbydou peníze na naše důchody a že nedostaneme kvalitní vzdělání. A protože se těchto důsledků bojíme, máme přesvědčit naše prarodiče $\mathrm{k}$ volbě pravice.

Schéma argumentu apelujícího na $\operatorname{strach}^{64}$ má podle Waltona následující schéma ${ }^{65}$ :

P1: Pokud nevykonáš A, stane se D.

P2: D je velmi špatné.

P3: Tedy, měl bys zabránit $\mathrm{D}$, pokud je to možné.

P4: Jediný způsob, jak zabránit $\mathrm{D}$, je udělat A.

$\mathrm{Z}$ : Měl bys udělat A.

V první premise je uveden charakter hrozby: hrozí, že pokud nevykonáme určitý čin, nastanou určité důsledky. Ve druhé premise se konstatuje, že jde o negativní důsledky. Třetí premisa z toho odvozuje nutnost zabránit tomu, aby důsledky nastaly. Ve čtvrté premise je potvrzeno, že existuje

63 Walton, Reed \& Macango (2008, s. 105).

64 Tamtéž, s. 104.

65 Walton (2013, s. 143). 
určitý čin, který může důsledkům zabránit. V závěru argumentu je deklarována nutnost vykonat tento čin.

Pokud zapíšu identifikovaný argument jako instanci schématu argumentu apelujícího na strach, dostanu tento zápis:

P1a ${ }^{66}:$ Jestli v České republice zvítězí levicové strany, bude to zásluhou seniorů.

P1b: Typičtí voliči levice jsou senioři a mohou být naši př́ibuzní.

P2: Vítězství levice povede ke špatným důsledkům.

P3: Mladí lidé by měli změnit osud České republiky k lepšímu, je-li to možné.

P4: Přemluvením př́ibuzných seniorů můžeme změnit osud České republiky k lepšímu.

$\mathrm{Z}$ : Měli bychom přemluvit své prarodiče $\mathrm{k}$ volbě pravicové strany.

V první premise je popsán charakter hrozby, totiž že senioři volící levici mohou způsobit výhru levice. Druhá premisa P2 konstatuje, že výhra levice je negativní důsledek, spočívající ve špatném osudu České republiky. $\mathrm{V}$ třetí premise je deklarována nutnost zabránit negativním důsledkům, která je dána naší povinností změnit osud k lepšímu, mámeli k tomu možnost. Premisa P4 ukazuje jednání, které povede k odvrácení těchto důsledků, tedy přemluvení našich příbuzných seniorů $\mathrm{k}$ volbě pravicové strany. Závěrem argumentu je tvrzení, že bychom tedy měli naše prarodiče přemluvit. Vidíme, že PZ-struktura vytvořená v rámci první výzkumné otázky velmi dobře připomíná strukturu schématu argumentu apelujícího na strach. Pokud bych však chtěl vytvořit strukturu zcela stejnou, mohl bych změnit formulace jednotlivých premis tímto způsobem:

P1: Pokud nepřemluvíme seniory, zvítězí levice.

P2: Vítězství levice je špatné.

66 V zápise jsem premisu schématu P1 rozdělil do dvou částí, aby odpovídala premisám naší PZstruktury, jejíž premisy P1 a P2 popisují charakter hrozby. 
P3: Měli bychom zabránit vítězství levice, pokud je to možné.

P4: Jediný způsob, jak zabránit vítězství levice je přemluvit seniory, aby volili pravici.

Z: Měli bychom přemluvit své prarodiče $\mathrm{k}$ volbě pravicové strany.

Z předložené formulace je patrné, že se mi povedlo úspěšně identifikovat Waltonovo argumentační schéma argumentu apelujícího na strach, čímž jsem zodpověděl druhou výzkumnou otázku. V následující části textu budu pokračovat $\mathrm{v}$ odpovědi na poslední výzkumnou otázku: zjistím, zda jsou v textu zodpovězeny kritické otázky, které se ke schématu vztahují.

Jelikož nalezené schéma nemá otázky definovány, použiji otázky obecnějšího schématu argumentu z negativních důsledků. Argument apelující na strach je jeho podtypem, bude mít tedy i stejné kritické otázky. Walton stanovuje tři ${ }^{67}$ :

1. Jak velká je pravděpodobnost, že důsledky nastanou, mohou nastat nebo musí nastat?

2. Jaké důkazy podporují tvrzení, že důsledky nastanou, mohou nebo musí nastat? A jsou dostatečné, aby podpořily sílu tvrzení adekvátně?

3. Mohou nastat i nějaké pozitivní důsledky, které by se měly brát v potaz?

Argument apelující na strach je speciálním případem argumentu z negativních důsledkươ ${ }^{68}$. Přesněji ho rozšiřuje o další dvě premisy, a proto lze předpokládat, že kritické otázky pokrývají právě tu část

67 Walton, Reed \& Macango (2008, s. 102).

68 Waltonův argument $\mathrm{z}$ negativních důsledků:

P1: Když není vykonáno A, nastanou důsledky B.

P2: Důsledky B jsou z mého pohledu špatné.

Z: A by mělo být vykonáno. 
argumentu apelujícího na strach, která se negativních důsledků týká. Bylo by nejspíše potřeba podrobit kritice i dalšr části argumentu ${ }^{69}$, jelikož ale vycházím z Waltonovy metodologie, přidržím se jím identifikovaných kritických otázek. Navíc se domnívám, že kritické otázky cílí na nejslabší místo argumentu, tedy tam, kde je argument nejnáchylnějšś $k$ chybě. Jedná se o místo, kde jsou deklarovány negativní důsledky. Jde tedy o druhou premisu argumentu, kde se tvrdí, že vítězství levice je špatné.

Cílem první otázky je zjistit, jestli jsou deklarované negativní důsledky opravdu uskutečnitelné. Mohlo by se např́klad ukázat, že jsou jen málo pravděpodobné a mohou nastat jen ve velice specifickém případě, nebo že jsou naopak velmi pravděpodobné. Jelikož se na argument dívám optikou negativních důsledků, mám tak podle první kritické otázky určit, jaká je pravděpodobnost, že volba levice povede $\mathrm{k}$ negativním důsledkům.

Protagonisté tvrdí, že volba levice povede ke špatným důsledkům zcela jistě. Přesněji tvrdí, že osud České republiky nebude dobrý, pokud zvítězí levice, ale bude špatný, jak je obsaženo v premise $\mathrm{P}^{70}$. Takto silné tvrzení se ale bude velmi těžko obhajovat, nebot tak vágní pojem jako lepší (respektive horší) osud země musíme nejdříve definovat, abychom o něm mohli vést debatu. Diskuse, zda bude osud České republiky lepš́í, nebo horší, pokud ve volbách vyhraje levice, nebo pravice, bude jistě jádrem sporu mezi příznivci těchto dvou politických směrů. Pokud přistoupíme na to, že tato dichotomie mezi levicí a pravicí v české politice existuje, a na to, že lze rozhodování o hlasování ve volbách zjednodušit na rozhodnutí mezi jakoukoliv levicovou, nebo pravicovou stranou, musíme očekávat velmi vágní debatu. Mádl a Issová na toto zjednodušení přistoupili a ve sporu se jasně přiklánějí na stranu pravice. $Z$ hlediska Waltona není otázka zodpovězena uspokojivě, protože pro část př́jjemců argumentu, těch z tábora př́iznivců levice, nebudou odpovědi přesvědčivé, jak se ukáže při odpovědi na druhou kritickou otázku.

Ta cílí na možné doklady toho, že negativní důsledky skutečně nastanou. Jejím smyslem je odhalit princip, který podporuje tvrzení,

69 Např́klad by nás mohlo zajímat, proč se důsledkům bránit - což je deklarováno v premise $\mathrm{P}_{3}$-, dále neexistuje-li jiný čin, kterým by se mohly důsledky odvrátit - což je tvrzeno v premise $\mathrm{P} 4$ a podobně.

70 Z hlediska celého argumentu, jehož PZ-strukturu jsem popsal výše, jde o premisu P3. 
že hrozba je skutečně možná. Jakými důkazy podporují protagonisté tvrzení, že dojde $\mathrm{k}$ negativním důsledkům? Uvádějí čtyři oblasti, ve kterých je levicová politika špatná: státní rozpočet, lékařská péče, důchodový systém a školství. V prvním případě tvrdí, že levice nadělá dluhy, kvůli čemuž nezbydou ve státní kase v budoucnosti peníze. Tyto dluhy pak budou v budoucnosti splácet dnes mladí lidé. Za druhé levice zruší regulační poplatky u lékaře, což povede ke zhoršení kvality lékařské péče. Mádl to formuluje tak, že jeho osobně, jakožto zástupce mladých lidí, toto rozhodnutí poškodí. Dále levice nereformuje důchodový systém, a tak nebudou v budoucnosti peníze na důchody. Nakonec, za čtvrté, levice nezavede školné na vysokých školách, které je podle Mádla jediným prostředkem $\mathrm{k}$ tomu, aby se motivovaly školy ke zlepšení. Důsledkem toho dojde k odlivu nadaných Čechů do zahraničí. V těchto čtyřech oblastech je podle protagonistů levicová politika špatná a, pokud levice zvítězí, budou tyto čtyři piliuře státní sféry v budoucnu ve velmi špatném stavu. Issová a Mádl tedy podporují tvrzení, že volba levice povede ke špatným důsledkům tím, že konkrétně popisují čtyři negativní důsledky levicové politiky a vysvětlují, proč by k nim mělo dojít. Jejich důkazy ovšem vycházejí z pravicových argumentů a z jejich pohledu na to, jaké jsou nutné a správné reformy. Opět tedy nelze automaticky počítat s tím, že by s důvody souhlasil levicový volič.

Poslední otázka se snaží oslabit pojem negativních důsledků, které mají podle předkladatelů nastat. Pokud by se ukázalo, že existují i nějaké pozitivní důsledky, které jsou s těmi negativními spojeny, mohli bychom např́klad uvažovat o tom, jakou váhu protichůdné důsledky mají, čímž by byl argument značně oslaben. Žádné pozitivní důsledky však protagonisté nezmiňují ani jako např́klad vedlejší efekt těch negativních. Existují ale nějaké? Protagonisté videa by nejspíše tvrdili, že neexistují, nebo pokud existují, mají mnohem menší váhu než ty negativní. $V$ tom by se lišili od jejich odpůrců, zastánců levice ${ }^{71}$.

Nyní mohu odpovědět na poslední výzkumnou otázku. Kritické otázky nejsou zodpovězeny uspokojivě. Problém spočívá v tom, že by odpovědi na kritické otázky neobstály u příznivců levice. Podíváme-

71 Ti by jistě mohli předložit řadu příkladů dobrých důsledků vítězství levice a také př́klady negativních do̊sledků plynoucích z výhry pravice. 
li se totiž na argument perspektivou mladého voliče levice, vidíme, že dokud nebude přesvědčen o tom, že vítězství levice povede ke špatným důsledkům, a tedy zároveň že vítězství pravice povede $\mathrm{k}$ dobrým, nebude argumentem Issové a Mádla motivován $\mathrm{k}$ tomu, aby přemluvil své prarodiče $\mathrm{k}$ volbě pravice. Nebude totiž mít $\mathrm{z}$ deklarovaných negativních důsledků - vítězství levice - strach. Argument nemůže obstát bez toho, aby přesvědčil mladého voliče levice o tom, že má změnit názor a sympatizovat s pravicí. Ukazuje se, že nejslabší místo argumentu je právě bod, ve kterém protagonisté tvrdí, že vítězství levice je špatné.

Na druhou stranu může být argument úspěšný v př́ípadě potenciálních mladých voličů pravice. Pravděpodobně by na ně argument apelující na strach působil, jelikož by se mohli obávat negativních důsledků v podobě vítězství levice. Vyvolání strachu by považovali v dané situaci za legitimní a souhlasili by se závěrem argumentu. $V$ důsledku toho by měli mít zájem přesvědčit své prarodiče $k$ volbě pravice.

Zajímavé by bylo sledovat, jak by argument obstál u nerozhodnutých mladých voličů. Tedy těch, kteří nevědí, zda volit levici, nebo pravici, nebo dokonce těch, kteří ani nechtějí jít volit. Domnívám se, že právě tato skupina mladých je nejpravděpodobnější cílová skupina pro autory videa. Je totiž velká šance, že u těchto potenciálních voličů vyvolá argument zdůrazňující negativní důsledky vítězství levice strach. Vždyt’ se jich důsledky budou v budoucnosti prrímo dotýkat. Proto by se mohli rozhodnout $\mathrm{k}$ volbě pravicové strany, a dokonce by i mohli chtít přesvědčit své prarodiče, aby učinili stejně.

Zda by na ně ale argument působil, můžu posoudit pouze pomocí zodpovězení kritických otázek. Výše jsem přitom ukázal, že otázky jsou zodpovězeny dostatečně pro voliče pravice, ale naopak pro voliče levice ne. Nerozhodnutí mladí voliči se nejspíše budou pohybovat někde mezi těmito dvěma extrémy. $Z$ této skupiny je pak nejzajímavější podskupina $\mathrm{s}$ nevyhraněnými preferencemi. Waltonův nástroj mi bohužel v tomto místě neumožní říci, jak by na ně předložený argument působil. Nemohu určit, zda jsou kritické otázky pro tyto př́jemce argumentu dostatečně dobře zodpovězeny. Museli bychom sledovat konkrétní debatu o negativních dopadech levicové politiky ve čtyřech zmíněných bodech. 
Nakonec se tedy nabízí otázka, vzhledem k jakým př́ijemcům argument hodnotit. Domnívám se, že vzhledem k těm, kteří by argument automaticky nepřijali, protože ti, kteří ho přijmou automaticky, nejsou z hlediska přesvědčování zajímaví. Proto musím odpovědi protagonistů na kritické otázky považovat za neuspokojivé.

\section{Závěr}

Na základě předchozí kapitoly mohu zodpovědět výzkumné otázky.

\section{O1: Jaká je PZ-struktura hlavního argumentu ve videu Přemluv bábu?}

Podařilo se mi zachytit PZ-strukturu argumentace. Identifikoval jsem jeden komplexní argument, jehož závěr zní: Mladílidé by měli přesvědčit své prarodiče, aby volili (novou) pravicovou stranu. Argument je složen z 11 premis, z nichž čtyři jsou implicitní. Parafrázi jsem formuloval následovně:

Měli bychom přemluvit své prarodiče $k$ volbě pravicové strany, protože naši př́buzní senioři jsou typičtí voliči levice, díky kterým může levice vyhrát. Zvolení levice ale povede ke špatným důsledkům a my jsme povinni změnit osud České republiky $k$ lepšímu, máme-li jak. A právě přemluvením seniorů, kteř́ neumí adekvátně ohodnotit chování levice v minulosti, změníme osud země k lepšímu.

Neformálně-logická analýza se ukázala jako vhodný nástroj pro základní práci se zvoleným materiálem. Povedlo se mi díky ní rekonstruovat argumenty v co nejsilnější podobě a odstranit nepodstatné složky materiálu. Na konkrétním příkladu jsem tak ukázal, jak neocenitelným nástrojem tento př́istup je.

O2: Jaká argumentační schémata jsou obsažena v nalezené PZ-struktuře? 
$\mathrm{V}$ získané PZ-struktuře se mi podařilo identifikovat argumentační schéma argumentu apelujícího na strach. Schéma je složeno ze závěru a čtyř premis, které kopírují PZ-strukturu popsanou v rámci neformálnělogické analýzy. Ukázal jsem, že jde o př́pad obecnějš́ího schématu argumentu z negativních důsledků, a to o př́pad, jehož specifikem je snaha o vyvolání emocí, tedy strachu z negativních důsledků. V př́ípadě nalezeného argumentu jde o probuzení strachu $\mathrm{v}$ mladých lidech $\mathrm{z}$ toho, že politika levice $\mathrm{v}$ budoucnu povede $\mathrm{k}$ důsledkům, které pro ně budou nežádoucí.

\section{O3: Jsou v textu uspokojivě zodpovězeny kritické otázky, které se vztahují k nalezeným schématům?}

Uvedl jsem, že odpovědi na kritické otázky by mohly být uspokojivé pro mladé stoupence pravice. Mladé levicové voliče by ale pravděpodobně nepřesvědčily. Zda by přesvědčily nerozhodnuté voliče, nemůžeme pomocí Waltonova nástroje posoudit. A poněvadž chceme argument hodnotit s ohledem na jeho funkce napříč předvolební diskusí a z hlediska všech potenciálních př́jemců, považuji odpovědi za neuspokojivé.

Kritické dotazování je z principu dialogické a ke konečnému zhodnocení argumentace by podle Waltona mělo dojít během argumentačního střetu. Naznačil jsem proto, jak lze na otázky odpovědět na základě dostupného materiálu. Na základě analýzy mohu prohlásit, že argument neobstál. $\mathrm{V}$ tomto bodě by bylo potřeba, aby protagonisté odpověděli na to, co kritické otázky odhalily jako nedostatečné. Odpovědi by bylo samožrejmě možné dále rozvádět a kritizovat, dokud bychom nepovažovali kritické otázky za uspokojivě zodpovězené. To už bychom se ale pohybovali za hranicemi studovaného materiálu.

Povedlo se mi zodpovědět výzkumné otázky a dosáhnout předem stanoveného cíle. Představil jsem dva př́stupy $\mathrm{k}$ analýze argumentace a na konkrétním příkladu ukázal jejich silná a slabá místa. Dle mého názoru lze oba přístupy při analýze argumentace úspěšně použivat, pokud ovšem počítáme s jistými známými omezeními.

Jelikož jsem na začátku přijal předpoklad, že cílem videa je racionálně přesvědčit diváka pomocí slovně formulovaných argumentů, mohly mi některé důležité nonverbální aspekty videa uniknout. Video jako médium 
může na jednu stranu obsahovat přesvědčovací prostředky, které zvolené nástroje nezachytí. Na druhou stranu je ale většinou omezeno časem, takže v něm musí být slovní sdělení koncentrováno a argumenty musí být předloženy v krystalické podobě. Ve videu Přemluv bábu je bohužel na úkor humoru a nadsázky dobrých krystalických argumentů málo, mnohem více se v něm klade důraz na emoce. Dokonce hlavní argument textu spočívá ve vyvolání strachu o osud České republiky. Konkrétně má vyvolat strach př́jemců argumentu, mladých lidí, o jejich osud $\mathrm{v}$ budoucnosti.

Předmětem dalšího zkoumání by mohla být analýza rétorických aspektů argumentace, která by mi pomohla popsat další důležité přesvědčovací aspekty videa, které mnou zvolené nástroje nemohly zachytit. A dále také emocionální rozměr argumentace, který hraje $\mathrm{u}$ argumentu apelujícího na strach samožrejmě velmi důležitou roli. $\mathrm{K}$ tomu se ale nabízí jiné nástroje argumentační analýzy. ${ }^{72}$

\section{Literatura}

Blair, J. A. (1998): „Walton's Argumentation Schemes For Presumptive Reasoning: A Critique And Development." In Rozenberg Quarterly, ISSA Proceedings 1998. [cit. 4. 11. 2018]. Dostupné z: http://rozenbergquarterly.com/issa-proceedings-1998waltons-argumentation-schemes-for-presumptive-reasoning-acritique-and-development/.

Blair, J. A. (2011): Groundwork in the theory of argumentation. Springer, New York.

Blair, J. A. \& Johnson, R. H. (2006): Logical self-defence. International Debate Education Association, New York.

van Eemeren, F. H., Garssen, B., Krabbe, E. C., Snoeck Henkemans, A. F., Verheij, B. \& Wagemans, J. H. (2014): Handbook of Argumentation Theory. Springer, Dordrecht.

Freeman, J. B. (2012): „Anthony Blair (2012): Groundwork in the Theory of Argumentation." Argumentation 26 (4): 505-527. https://doi.org/10.1007/s10503-012-9276-5.

72 Viz další články v této publikaci. 
Groarke, L. (2017): „Informal Logic.“ In The Stanford Encyclopedia of Philosophy [online]. Stanford University [cit. 4. 11. 2018]. Dostupné z: https://plato.stanford.edu/archives/spr2017/ entries/logic-informal/.

Hansen, H. V. \& Cohen, D. H. (2011): „Are there methods of informal logic?" In Argumentation: Community and Cognition, Proceedings of the 9th Conference of the OSSA [online], ed. F. Zenker, University of Windsor, Windsor, vol. 9, 2011 [cit. 8. 11. 2018]. Dostupné z: https://scholar.uwindsor.ca/ ossaarchive/OSSA9/papersandcommentaries/15/.

Hitchcock, D. (2006): The concept of argument, and informal logic. McMaster University, Hamilton. Dostupné z: https://www. humanities.mcmaster.ca/ hitchckd/informal.pdf.

Issová, M., Mádl, J. \& Zelenka, P. (2010): „Přemluv bábu.“ In Youtube [online]. 22. 4. 2010 [cit. 8. 11. 2018]. Dostupné z: https://www. youtube.com/watch? $\mathrm{v}=$ MLfFhdcXJhA.

Lumer, Ch. (2016): „Waltons's Argumentation Schemes.“ In OSSA Conference Archive, Proceedings of OSSA Conference [online]. University of Windsor, Windsor, vol. 11, 2016 [cit. 8. 11. 2018]. Dostupné z: https://scholar.uwindsor.ca/ossaarchive/OSSA11/ papersandcommentaries/110/.

Ondráček, T. \& Štěpánek, J. (2016): „Nástin koncepce adaptivních logik." Pro-Fil 17 (1): 16-35. https://doi.org/10.5817/pf16-1-1451.

Pezlar, I. (2012): „Je nemonotónní logika logikou?“ Pro-Fil 13 (1): 4151. https://doi.org/10.5817/pf13-1-297.

Siegel, H. (1988): Educating reason: rationality, critical thinking, and education. Routledge, New York.

Walton, D. (2005): „Justification of argumentation schemes.“ The Australasian Journal of Logic 3: 1-13. Dostupné z: https://ojs. victoria.ac.nz/ajl/article/view/1769.

Walton, D. (2013): Scare Tactics: Arguments that Appeal to Fear and Threats. Springer. Argument and Computation.

Walton, D. \& Godden, D. (2007): „Advances in the theory of argumentation schemes and critical questions." Informal Logic 27 (3): 267-292. https://doi.org/10.22329/il.v27i3.485. 
Walton, D. \& Reed, Ch. (2002): „Argumentation Schemes and Defeasible Inferences." In Proceedings of the ECAI 2002 Workshop on Computational Models of Natural Argument [online], eds. G. Carenini, F. Grasso, \& C. Reed, Lyon, 2002, s. 25-29. [cit. 4. 11. 2018]. Dostupné z: http://www.cmna.info/ a http://www.dougwalton.ca/papers\%20in\%20pdf/2002Reed. pdf.

Walton, D. \& Reed, Ch. (2007): „Argumentation Schemes in Dialogue.“ In OSSA Conference Archive, Proceedings of the OSSA Conference [online]. University of Windsor, Windsor, vol. 7, 2007 [cit. 8. 11. 2018]. Dostupné z: https://scholar.uwindsor.ca/ ossaarchive/OSSA7/papersandcommentaries/122/.

Walton, D., Reed, Ch. \& Macango, F. (2008): Argumentation schemes. Cambridge University Press, New York.

\begin{abstract}
Convince Your Grandma Because There Are Reasons to Be Afraid: Walton's Argumentation Schemes in the Video „Convince Your Grandma"

In an article, I present two approaches to argumentation analysis: an informal logic analysis based on the work of Ralph H. Johnson and J. Anthony Blair and an analysis using Douglas Walton's Argumentation schemes. In the first part of the paper, I define both approaches and explain their relationship. I also define the basic concepts of both approaches - the argument, the internal argument, the implicit premise, the structure of the premises and conclusion, the argumentation scheme and the critical questions. I also challenge their advantages and disadvantages. In the second part of the text, I apply the defined tools to the video Přemluv bábu (Convince your grandma, 2010). I put forward three research questions to answer. The aim of the first question is to depict the structure of the premises and conclusion of the argument in the video. The second question aims to seek argumentation schemes in the structure. Here I consider the most important argument from a fear appeal. The aim of the last question is to find the answers to the critical questions related to the argument from fear appeal. I come to the conclusion that the protagonists do not answer the questions satisfactorily. The intention of the paper is to present a case study on how to analyze an argumentation text using the selected approaches.
\end{abstract}


Keywords: argumentation, analysis, informal logic analysis, Douglas Walton, Convince your grandma

Prokop, M. (2018): „Přemluv bábu, protože je čeho se bát, aneb Waltonova argumentační schémata ve videu „Přemluv bábu“.Filosofie dnes 10(2): 94-125. Dostupné z www.filosofiednes.ff.uhk.cz 